\title{
JUVENILE HEIGHT GROWTH RATES AND SORTING OF THREE NOTHOFAGUS SPECIES ON AN ALTITUDINAL GRADIENT
}

\section{TASAS DE CRECIMIENTO JUVENILES Y DISTRIBUCION DE TRES ESPECIES DE NOTHOFAGUS EN UN GRADIENTE ALTITUDINAL}

\author{
Cecilia Cárdenas Garrido ${ }^{1}$ \& Christopher H. Lusk ${ }^{1,2}$
}

\begin{abstract}
It has been argued that if the cost of investment in cold resistance mechanisms detracts significantly from growth rates, then height growth tradeoffs should control species sorting on latitudinal temperature gradients. Applying the same logic to altitudinal temperature gradients, it can be predicted that species' upper altitudinal limits will be fixed by their degree of cold resistance, whereas the lower altitudinal limits of species growing higher up will be set by competition from faster-growing thermophilous species. We tested this prediction for three Nothofagus species on an altitudinal gradient $(1,100-1,700 \mathrm{~m})$ near Termas de Chillán, on the lower western slopes of the Andean Cordillera. We used retrospective methods to measure height increment during the previous growing season, for juvenile trees growing under open conditions at 12 sites. As expected, height growth rates generally decreased with increasing altitude. However, relationships between altitude and height growth did not differ among species. As growth rates of cold-resistant $N$. pumilio were very similar to those of its more thermophilous competitors $N$. obliqua and $N$. dombeyi, our initial prediction was not upheld by the data, and we can not explain what determines the lower altitudinal limit of $N$. pumilio.
\end{abstract}

Keywords: altitude, cold resistence, competition, temperate forest, tradeoff

\footnotetext{
${ }^{1}$ Departamento de Botánica, Universidad de Concepción, Casilla 160-C, Concepción, Chile

${ }^{2}$ Author to whom correspondence should be directed. Email clusk@udec.cl
}

\section{RESUMEN}

Se ha postulado que, si la inversión de las especies arbóreas en mecanismos de resistencia al frío es a costa de la tasa de crecimiento, entonces la distribución de las especies a lo largo de los gradientes latitudinales de temperatura debería ser determinada por un compromiso entre el crecimiento en altura y la resistencia al frío. Aplicando la misma lógica a los gradientes altitudinales, se puede predecir que mientras los límites superiores de las especies serán fijados por su capacidad de resistir el frío, sus límites inferiores en el gradiente serán determinados por la competencia con especies de crecimiento más rápido. Pusimos a prueba esta idea con un sistema modelo de tres especies de Nothofagus, en un gradiente altitudinal (1100 - $1700 \mathrm{~m})$ cerca de Las Termas de Chillán, en las faldas occidentales de la Cordillera de los Andes. Utilizamos métodos retrospectivos para medir el crecimiento en altura durante la temporada anterior, en árboles juveniles en 12 sitios con condiciones abiertas. De acuerdo a nuestras expectativas, por lo general las tasas de crecimiento en altura disminuyeron con el aumento en altitud. Sin embargo, las relaciones entre altitud y tasa de crecimiento no difirieron estadísticamente entre especies. Dado que las tasas de crecimiento de $N$. obliqua, resistente al frío, fueron muy similares a las de sus congéneres más termófilas $N$. obliqua y $N$. dombeyi, no se apoyó nuestra predicción inicial. Por ende, nuestros datos no permiten explicar las causas del límite altitudinal inferior de $N$. pumilio.

Palabras Claves: altitud, bosque templado, competencia, tolerancia al frío 


\section{INTRODUCTION}

The ecological literature reveals fairly consistent patterns of belief about the determinants of species' range limits on environmental gradients (Brown et al. 1996). It has often been suggested that biotic interactions reduce abundance to zero at the more productive limits of a given species' range, whereas abiotic factors are held to restrain species towards the harsher reaches of their range (Dobzhansky 1950; MacArthur 1972; Grime 1977). Although there has been empirical confirmation of this pattern for some environmental gradients (e.g. intertidal zones: Connell 1961), data are scarce for others.

An explicit mechanistic model has been proposed for tree species' range limits on latitudinal temperature gradients (Loehle 1988). Trees can tolerate seasonally low temperatures by physiological mechanisms such as accumulation of solutes which enable supercooling, as well as production of cryoprotective proteins (Sakai \& Larcher 1987). Many cold-tolerant trees also have conservative growth strategies, minimising risks of frost damage by late bud burst (Loehle 1998). As all of these cold resistance mechanisms are likely to detract from annual growth rates, height growth tradeoffs should control species sorting on latitudinal temperature gradients (Loehle 1998). As a result, the poleward limits of species' distributions should be fixed by their degree of cold resistence, whereas their lower latitudinal limits should be determined not primarily by an intolerance of higher temperatures, but by competition from fastergrowing species which overtop them.

The same logic can be applied to altitudinal temperature gradients. It can be predicted that species' upper altitudinal limits will be fixed by their degree of cold resistence, whereas the lower altitudinal limits of species growing higher up will be set by competition from faster-growing but less cold-tolerant species. There is considerable empirical support for the first prediction, that species' upper limits are largely a function of cold resistence (Sakai et al. 1981; Alberdi et al. 1985; Sakai \& Larcher 1987; Cabrera 1996). However, at this stage there are few data relevant to the causes of species' lower limits.

We tested one of the predictions of Loehle's (1988) hypothesis for three Nothofagus species on an altitudinal gradient near Termas de Chillán, on the lower western slopes of the Andean Cordillera. If the hypothesis is applicable to altitudinal gradients, then height growth rates of the coldtolerant timberline species $N$. pumilio (P. et E.) Krasser, should be inferior to those of the more thermophilous $N$. obliqua (Mirb.) Oerst and $N$. dombeyi (Mirb.) Oerst, on sites where these species' distributions overlap. As all three of these shadeintolerant Nothofagus spp. establish mainly beneath canopy openings (Veblen et al. 1995), their relative competitiveness should be at least partly a function of comparative height growth rates of juveniles under open conditions (Lusk \& Matus 2000).

\section{METHODS}

\section{STUdy SitES}

Sampling was carried out on an altitudinal gradient leading to Termas de Chillán ( $36^{\circ} 52^{\prime} \mathrm{S}$; $71^{\circ} 28^{\prime} \mathrm{W}$ ), located near the timberline at $c a .1,800$ $\mathrm{m}$ a.s.l. The lower slopes of the Andes at this latitude experience a marked summer drought, lying as they does in the transition zone between the Mediterranean climate of central Chile and the temperate zone further south. As the study was directed at species sorting on temperature gradients, sampling was therefore restricted to sites $>1,000 \mathrm{~m}$ a.s.l. where annual precipitation exceeds $2,000 \mathrm{~mm}$ (Almeyda \& Saez 1958), and where tree growth is less likely to be strongly limited by water availability during the growing season.

Most remaining forest in the area is secondgrowth. The deciduous Nothofagus obliqua dominates the overstorey below $c a$. 1,400 m, except along drainage lines and near water courses where the evergreen $N$. dombeyi can be locally more abundant. These species overtop shorter broadleaved evergreen trees such as Persea lingue (R. et P.) Nees ex Kopp, Gevuina avellana Molina and Lomatia hirsuta (Lam.) Diels ex Macbr. , and less commonly the conifers Austrocedrus chilensis (D. Don) Pic. Ser. et Bizz., Podocarpus saligna D. Don and Prumnopitys andina (Poepp. Ex Endl.) de Laub. The deciduous $N$. pumilio replaces $N$. obliqua as the overstorey dominant at $c a .1,400 \mathrm{~m}$, and forms the timberline at $c a .1,800 \mathrm{~m}$. However $N$. pumilio also occasionally appears below 1,400 m, usually 
near streams. In keeping with expectations arising from the relative latitudinal and altitudinal distributions of the study species, measurements show that $N$. pumilio is considerably more frost resistant than $N$. dombeyi (Alberdi et al. 1985) and probably also more so than $N$. obliqua (Murray et al. 1986).

SAMPLING

We subjectively chose 12 open sites where juveniles of at least one of our study species were present, at altitudes ranging from 1,100 to $1,700 \mathrm{~m}$ (Table I). At each site, 10 sampling points were located at random intervals along a $50 \mathrm{~m}$ transect, and the nearest juvenile (100 to $300 \mathrm{~cm}$ tall) of each species was selected at each point. Height growth of each individual during the previous growing season (2000-2001) was determined by measuring the distance from the apex to the most recent resting bud scar, which is easily distinguishable in Nothofagus. Altitude at each site was measured with a global positioning system, verified a posteriori from topographic maps.

\section{DATA ANALYSIS}

Analysis of covariance was used to examine the effect of altitude and species on height growth rates. For each site where more than one species was present, the Tukey-Kramer test was test for significant differences between sympatric growth rates of the different species. All analyses were carried out with JMP Statistical Software (SAS Institute, Cary, NC).

\section{RESULTS}

Average height increment for the 20 populations studied ranged from $c a$. 220 to $540 \mathrm{~mm}$ during the 200-2001 growing season (Table I). Growth rates were marginally negatively correlated with altitude (Table II; Fig. 1). However, species differed neither in the intercept nor slope of this relationship (Table II). Sympatric comparisons showed that there were no significant differences between species pairs at any site (Tukey-Kramer, $\mathrm{P}$ $>0.05)$.

TABLE I. Height increment (mm) during 2000-2001 growing season (mean \pm s.e.) of three Nothofagus species at 12 sites differing in altitude, Termas de Chillán, Chile. Sample size per population $=8$ to 10 .

\begin{tabular}{|c|c|c|c|c|}
\hline Altitude (m) & N. obliqua & N. dombeyi & N. pumil & ilio \\
\hline 1110 & $460 \pm 48$ & $454 \pm 49$ & - & \\
\hline 1220 & $276 \pm 16$ & - & - & \\
\hline 1275 & $361 \pm 49$ & $430 \pm 95$ & - & \\
\hline 1290 & $527 \pm 61$ & $442 \pm 66$ & $414 \pm$ & 62 \\
\hline 1300 & $379 \pm 45$ & $329 \pm 33$ & - & \\
\hline 1340 & $249 \pm 48$ & $319 \pm 52$ & - & \\
\hline 1370 & $479 \pm 85$ & - & $538 \pm$ & 99 \\
\hline 1450 & - & - & $262 \pm$ & 39 \\
\hline 1475 & $255 \pm 32$ & - & $285 \pm$ & 15 \\
\hline 1580 & - & - & $218 \pm 2$ & 29 \\
\hline 1650 & - & - & $257 \pm$ & 39 \\
\hline 1700 & - & - & $304 \pm$ & 39 \\
\hline
\end{tabular}


Gayana Bot. 59(1), 2002

TABLE II. ANCOVA showing effects of altitude and species on height growth rates of juvenile Nothofagus, Termas de Chillán.

$\begin{array}{llll}\text { Source of variation } & \text { d.f. } & \text { F- ratio } & \text { P } \\ & & & \\ & 1 & 3.97 & 0.066 \\ \text { Altitude } & 2 & 0.27 & 0.768 \\ \text { Species } & 2 & 0.06 & 0.938 \\ \text { Altitude X species } & & \end{array}$

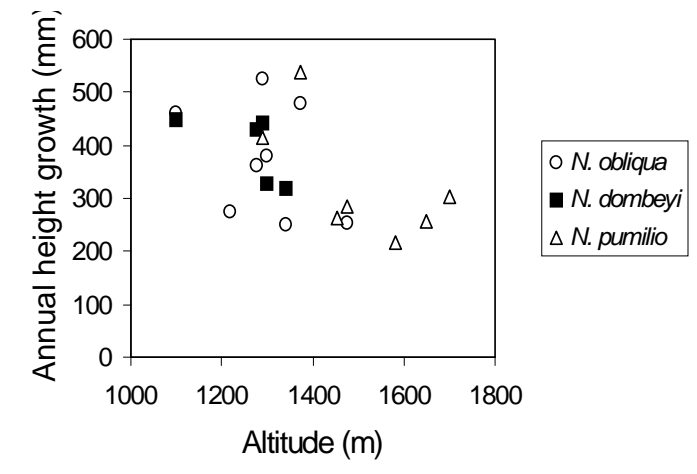

Figure 1. Variation in height growth rate of saplings of three Nothofagus species on an altitudinal gradient, Termas de Chillán, Chile.

\section{DISCUSSION}

Height growth rates reported here are of a similar order to those for New Zealand species of Nothofagus on montane sites (Wardle 1984). The reduction of Nothofagus height growth with increasing altitude also appears to be typical of altitudinal gradients in New Zealand, although this trend is sometimes reversed on lowland sites subject to severe water stress (Wardle 1984). Although altitudinal gradients generally confound numerous environmental variables of physiological importance (Ogden \& Powell 1979; Burns \& Leathwick 1996), the decline in height growth with increasing altitude is at least partly attributable to a reduction in temperatures and in growth season length.

There was no evidence that juveniles of coldtolerant Nothofagus pumilio grew slower than those of its more thermophilous associates (Fig. 1; Tables I-II). All three species showed very similar growth responses to the altitudinal gradient, and sympatric growth rates were statistically indistinguishable in all cases. Our data therefore do not support the suggestion by Loehle (1998) that cold resistence in species such as is $N$. pumilio necessarily implies a sacrifice of juvenile height growth potential. It follows that our data do not support the proposal that the lower altitudinal limit of $N$. pumilio is determined by its saplings being outcompeted by faster-growing competitors such as $N$. obliqua and N. dombeyi.

What then determines the lower altitudinal limit of N. pumilio? It seems unlikely that $N$. pumilio is intolerant of climatic regimes prevailing below $1,400 \mathrm{~m}$, as shown by its occasional appearance further downslope. Although the lowest population included in the present study was located at 1,290 $\mathrm{m}$ (Table I), isolated individuals are occasionally found near watercourses as low as 1,200 m, presumably resulting from downstream dispersal of seeds.

The relatively low maximum height of $N$. pumilio may limit its ability to compete with taller congeners such as $N$. obliqua and $N$. dombeyi. Sympatric comparisons show that the latter two species can overtop $N$. pumilio by at least $10 \mathrm{~m}$ (Veblen et al. 1980). As all three are similarly shadeintolerant (Veblen et al. 1995), this difference could reduce $N$. pumilio to the status of a fugitive species below the upper altitudinal limit of $N$. dombeyi and $N$. obliqua. Although $N$. pumilio can 
opportunistically capture low altitude sites if seed sources are available (e.g. on streambanks), its hold there is likely to be transient as a result of overtopping by taller-growing trees.

Interactions between $N$. pumilio and its congeners could also be mediated by natural enemies. Several Nothofagus species are known to suffer defoliation by lepidopteran caterpillars, and $N$. pumilio appears to be the most severely affected (Veblen et al. 1996). High mortality rates of $N$. pumilio as a result of insect attack could therefore help explain the predominance of $N$. obliqua and $N$. dombeyi below ca. 1,400 m.

We are not aware of any previous application of Loehle's (1998) hypothesis to altitudinal gradients. Although data from North American forests are consistent with Loehle's predictions about the causes of latitudinal gradients (Loehle 1998), our study of an altitudinal gradient failed to support the hypothesis. However, in view of the small sample sizes and limited scale of the present study, our conclusions must be regarded as very tentative. More extensive studies are required before ecologists can draw up generalisations about the relative importance of physiological tolerances and biotic interactions in fixing species' lower altitudinal limits.

\section{ACKNOWLEDGMENTS}

We are grateful to FONDECYT for funding, and to María Moreno for technical assistance.

\section{REFERENCES}

Alberdi, M., M. Romero, D. Ríos \& H. Wenzel. 1985. Altitudinal gradients of seasonal frost resistance of Nothofagus communities of southern Chile. Acta Oecologica 6: 21-30.

Almeyda, E. \& F. SÁEz. 1958. Recopilación de datos climáticos de Chile y mapas sinópticos respectivos. Ministerio de Agricultura, Santiago, Chile.

Brown, J.H., G.C. Stevens \& D.M. Kaufman (1996) The geographic range: size, shape, boundaries and internal structure. Ann. Rev. Ecol. Syst. 27: 597623.
Burns, B.R. \& J.R. Leathwick (1996) Vegetationenvironment relationships at Waipoua Forest, Northland, New Zealand. N. Z. J. Bot. 34: 79-92.

Cabrera, H.M. 1996. Temperaturas bajas y límites altitudinales en ecosistemas de plantas superiores: respuestas de las especies al frío en montañas tropicales y subtropicales. Rev. Chil. Hist. Nat. 69: 309-320.

Connell, J.H. 1961. The influence of interspecific competition and other factors on the distribution of the barnacle Chthamalus stellatus. Ecology 42: 410-423.

Dobzhansky, T. 1950. Evolution in the tropics. Am. Sci. 38: 209-211.

Grime, J.P. 1979. Plant Strategies and Vegetation Processes. Wiley, Chichester, England.

Loenle, C. 1998. Height growth rate tradeoffs determine northern and southern range limits for trees. J. Biogeog. 25: 735-742.

Lusk, C.H. \& F. MAtus. 2000. Juvenile tree growth rates and species sorting on a soil fertility gradient in Chilean temperate rainforest. J. Biogeog. 27: 10111020.

Macarthur, R.H. 1972. Geographical Ecology: Patterns in the Distribution of Species. New York: Harper \& Row.

Murray, M.B., M.G.R Cannell \& L.J. Sheppard. 1986. Frost hardiness of Nothofagus procera and $N$. obliqua in Britain. Forestry 59: 209-222.

Ogden, J. \& J.A. Powell. 1979. A quantitative description of the forest vegetation on an altitudinal gradient in the Mount Field National Park, Tasmania, and a discussion of its history and dynamics. Aust. J. Ecol. 4: 293-325.

SAKAI, A. \& W. LARChER. 1987. Frost survival of plants: responses and adaptation to freezing stress. In: BILLINGS, W.D., F. GOLLEY, O.L. LANGE, J.S. OLSON \& H. REMMERT (Eds.) Ecological Studies, Vol. 62. Springer-Verlag, Berlin.

Sakai, A. D.M. Paton \& P. Wardle. 1981. Freezing resistence of trees of the southern temperate zone, especially subalpine species of Australasia. Ecology 62: 563-570.

Veblen, T.T., C. Donoso, T. Kitzberger \& A.J. Robertus. 1996. Ecology of Southern Chilean and Argentinean Nothofagus forests. In: VEBLEN, T.T., R.S. HILL \& J. READ (Eds.) Yale University Press. The Ecology and Biogeography of Nothofagus Forests, pages 293-353. Yale University Press, New Haven.

Veblen, T.T., F.M. Schlegel \& B. Escobar. 1980. Structure and dynamics of old-growth Nothofagus forests in the Valdivian Andes, Chile. J. Ecol. 68: 1-31.

WARDLE, J. 1984. The New Zealand Beeches. New Zealand Forest Service, Christchurch. 